\title{
AVALANCHE EDUCATION FOR SKIERS
}

\author{
By François Valla \\ (Centre Technique du Génie Rural des Eaux et des Forêts, Domaine Universitaire de \\ Grenoble, B.P. I I4, 38402 Saint-Martin-d'Hères, France)
}

\begin{abstract}
The numbers of people rambling in the mountains is increasing every day. Consequently, the number of avalanche accidents is very significant. In France, the main mountain users organizations, headed by ANENA, work for a better education of those in the mountains. Various aspects of training courses and public information services are discussed.

Résumé. Education des skieurs de montagne en matière d'avalanches. De par une fréquentation sans cesse croissante, la montagne est le théâtre d'accidents d'avalanches nombreux. Les principales instances montagnardes françaises, au sein desquelles l'ANENA joue un rôle privilégié, ont essayé d'amplifier la formation et l'information des usagers. Les principales réalisations sont décrites dans ce texte.

Zusammenfassung. Erziehung von Schifahrern in Fragen der Lawinengefahr im Gebirge. Ständig wächst die Zahl der Touristen im Gebirge. Als Folge nimmt auch die Zahl der Lawinenunfälle zu. In Frankreich setzt sich die grösste Bergsteigerorganisation, geführt von der ANENA, für eine bessere Erziehung von Gebirgstouristen ein. Die wichtigsten Massnahmen werden in diesem Bericht aufgeführt.
\end{abstract}

\section{INTRODUGTION}

Ski mountaineering has been practised in the French Alps for about a century. The sport came from Scandinavia in about 1890 so that for many years now the mountains have been crossed in winter-time by skiers who are thus exposed to avalanche hazards. Mountain skiers and accidents were rare before the second World War, but since the r 950 os the number of people practising mountain ski-ing has been rapidly increasing. In 1978 ioo ooo people were participating in the sport.

About 30 people are killed by avalanches each year in France; more than half of these are skiers. For example, during the winter of $1977-7837$ avalanche accidents were reported involving I I 7 people and these led to 32 deaths and $3^{8}$ non-fatal injuries. Of the 37 accidents, 23 were to skiers, and of the I 77 persons caught in avalanches, 72 were skiers. Indeed, every year the number of victims increases as a result of increases in the extent of mountaineering.

An investigation still in progress is tackling the problem of the exact number of people moving in the mountains, in winter as well as in summer, in order to assess the risk of these mountain sports. It will be instructive to look at changes in the number of skiers compared to the number of accidents, because the precise aim of ski-ing education is to reduce the number of accidents.

\section{Mountain SKIERS AND THEIR EDUGATION}

The type of education given to a skier will depend upon the people by whom, and to whom, the education is given.

\section{(a) The professional instructors}

This category includes mainly guides and trainee guides, but snow and avalanche education is also in the hands of other mountain professionals: alpine ski instructors, cross-country ski instructors, ski-patrol personnel, avalanche-control personnel, and first-aid workers.

\section{(b) The voluntary instructors}

This category includes advanced amateurs who lead mountain-club groups : "instructeurs", "initiateurs", "chefs de caravanes", etc. 


\section{(c) The instructees}

L'Association Nationale pour l'Étude de la Neige et des Avalanches (ANENA).

ANENA is the association for the study of snow and avalanches. It was created after the severe winter of $1970-7 \mathrm{I}$. This organization joins together all French specialists in snow and avalanche work (university, public officials, private individuals, and so on).

The main organizations are:

-National Meteorology-Snow study centre (Météorologie Nationale, Centre d'Étude de la Neige - Grenoble);

- Snow and Avalanche Division-French Water and Forest Service (Division Nivologie du Centre Technique du Génie Rural, des Eaux et Forêts - Grenoble);

-Special Application Laboratory-Atomic Centre (Laboratoire des Applications Spéciales du Centre d'Étude Nucléaire de Grenoble);

- Glaciological Laboratory-National Scientific Research Centre (Laboratoire de Glaciologie du Centre National de Recherche Scientifique - Grenoble);

-Alpine Geographical Institute (Institut de Géographie Alpine - Grenoble);

—Civil National Security (Sécurité Civile de Paris).

Among its other tasks, ANENA has to educate ski mountaineers in aspects of snow and avalanche danger. This instruction includes

-courses and lectures in specialized schools,

-lectures for beginners,

- periods of both practical and theoretical training,

- the organization of meetings, conferences, etc., for specialists.

ANENA also produces teaching materials and resources: pictures, films, pamphlets, books, etc.

\section{Teaching methods}

Two complementary methods are available for safety education: written documentation and an agreed curriculum.

\section{Documentation}

It is, at last, possible to find good documentation in the matter of mountain safety. Manuals written by individuals, clubs, or administrative groups are now available. ANENA is at the moment finishing a handbook which contains a substantial section for skiers. Pamphlets are also produced which deal with security, material, and avalanche precautions.

Some organizations were created in France a few years ago charged with the role of providing such information as mountain forecasts, best seasonal routes, the amount of snow and its quality, approach, huts, route availability, etc. Two of the most important groups in this area are the Office de Haute Montagne, in Chamonix, covering the area of the Mont Blanc range, and the Centre d'Information Montagne et Sentier, in Grenoble, which covers the Alps. Some mountain clubs perform the same function:

The meteorological organization broadcasts daily a weather report with a 24 h forecast. Snow reports and avalanche forecasts are also disseminated. The information can be distributed either by printed report or by phone service. At times of high avalanche risk special reports are prepared for the news media. 


\section{Curriculum}

(I) Schools are provided for professional people. Three schools of this type are:

E.N.S.A. (École Nationale de Ski et d'Alpinisme): This is the French school for ski-ing and alpinism, and it gives year-long diploma courses to alpine guides and ski instructors.

E.N.S.N.F. (École Nationale de Ski Nordique du Fond), an equivalent organization for cross-country ski instructors.

E.M.H.M. (École Militaire de Haute Montagne), a school reserved for those undergoing military training.

Other technical schools prepare young people for mountain work. After examination, they enter E.N.S.A. or E.N.S.N.F.

(2) Training for professional groups: ANENA is closely concerned with the production of such courses. Some courses are given twice or three times a year, others every two or three years. The most important training courses are for:

-snow-control personnel,

-ski-station directors,

- mountain guides working in snowy conditions,

- civil servants working in regional administration,

- avalanche dogs and their handlers.

More than a thousand people have graduated so far from these training courses.

(3) Training for volunteer groups: These courses generally take place in specialized schools (e.g. E.N.S.A. for alpine ski).

(4) Training period for mountain users: Some mountaineering clubs, etc., such as the Club Alpin Français and Grenoble Université Montagne organize week-end training sessions. Skiers are shown safety material (avalanche radio, avalanche rope, balloons, etc.) and given the opportunity to use it. Avalanche techniques are taught and efficient search protocols are developed. This type of course needs further development for all mountain skiers.

\section{Conclusion}

For ten years France has been trying to develop ski-ing safety with appropriate curriculum and information. Each skier should know that snow is dangerous. Education in the matter of avalanche safety is as important to the mountain skier as is the ability to ski. 